\title{
A nova arca de Noé: os animais e a desaprovação da civilização na obra de Lygia Fagundes Telles
}

\author{
The New Noah's Ark: Animals and the Disapproval \\ of the Civilization in Lygia Fagundes Telles's Works \\ El nuevo arca de Noé: los animales y la desaprobación \\ de la civilización en la obra de Lygia Fagundes Telles
}

Alva Martínez Teixeiro*

\section{Resumo}

Este artigo considera o modo como os animais são apresentados na escrita de Lygia Fagundes Telles, avaliando opções temáticas como a solidão, a crueldade ou o pessimismo. $\mathrm{O}$ estudo analisa a significativa função do bestiário em suas obras, nas quais a autora usa os animais falantes, fantásticos e simbólicos para oferecer-nos um retrato crítico de uma rica e complexa sociedade burguesa, povoada por uma grande variedade de personagens. Além disso, o estudo analisa a originalidade dos romances e contos de Telles, dando destaque à constante presença de animais literários como um mecanismo ficcional, como uma representação simbólica da sociedade e como uma via para questionar o valor das normas sociais, dos princípios éticos e da nossa própria invenção como seres civilizados, destacando o mundo antinatural que criámos para nós próprios.

Palavras-chave: Lygia Fagundes Telles, ficção, bestiário, condição humana.

Abstract

This article considers how animals are presented in Lygia Fagundes Telles's writing, evaluating thematic choices, such as loneliness, cruelty or pessimism. This study analyses the significant role of the bestiary in her works, where the author uses talking, fantastic and symbolic animals to offer a critical portrait of a rich and complex bourgeois society peopled by a great variety of characters. Moreover, this study analyses the originality of Telles' novels and short stories, noting the constant presence of literary animals as a fictional device, as a symbolic representation of society and as a way of questioning the value of social norms, ethical values and human's own invention as civilized beings, drawing attention to the unnatural world we have created for ourselves.

Keywords: Lygia Fagundes Telles, fiction, bestiary, human condition.

\section{Resumen}

Este artículo examina la forma en la que los animales son presentados en la escritura de Lygia Fagundes Telles, evaluando opciones temáticas como la soledad, la crueldad o el pesimismo. Éste estudio analiza el significativo rol que el bestiario tiene en sus obras, en las cuales la autora usa animales parlantes, fantásticos y simbólicos para ofrecer un retrato crítico de la rica y compleja sociedad burguesa, poblada por una gran variedad de personajes. Además de ello, este estudio analiza la originalidad de las novelas y cuentos de Telles, destacando la constante presencia de los animales como un instrumento ficcional, como una representación simbólica de la sociedad y como un modo de cuestionar el valor de las normas sociales, de los principios éticos y nuestra propia invención como seres civilizados, subrayando el mundo antinatural que hemos creado para nosotros mismos.

Palabras-clave: Lygia Fagundes Telles, ficción, bestiario, condición humana.

\footnotetext{
* Universidade de Lisboa, Lisboa, Portugal. (Dorcid.org/0000-0002-8156-7732. E-mail: alvamteixeiro@campus.ul.pt
} 
Ut praesit piscibus maris et volatilibus caeli, et bestiis, universaeque terrae, omnique reptili, quod movetur in terra.

(Gênesis, I, 26)

A obra de Lygia Fagundes Telles é extraordinariamente original, mesmo num cânone tão heterodoxo e excepcional como o da literatura brasileira, presidido por Machado de Assis, Carlos Drummond de Andrade ou Clarice Lispector. Um cânone, aliás, a que a autora se vincula por diversas vias, pois, como Machado, privilegia o fascínio crítico provocado por uma ambígua humanidade - nomeadamente, por uma equívoca mentalidade burguesa - ou, como Clarice, cria um bestiário que subverte de modo perturbador os traços mais habituais dos animais - não os da natureza, evidentemente, mas os da cultura.

Nesse sentido, este artigo pretende examinar a condição surpreendente e originalmente heterodoxa da escrita de Lygia Fagundes Telles, através do estudo da atípica "Arca de Noé" que cria em seus textos como aguda expressão simbólica do mal-estar perante a civilização contemporânea.

Se no pensamento contemporâneo o bestiário se tornou banal, como demonstrou Gilbert Durand (1985, p. 71) ao destacar que os paradigmas culturais do animal são a formiga, a cigarra ou Mickey Mouse, a autora situa-nos perante uma renovação disruptiva, ma non troppo, pois, afinal, a sua é a obra de uma "escritora de linhagem humanista" (Coelho, 2002, p. 386). Consequentemente, a parte do discurso literário dedicada ao animal não escapa, como também acontece com a obra clariceana, ao pecado original da modernidade; isto é, o de ser um modelo perfeito de antropocentrismo e, por isso, o animal está a serviço do homem e de seu estudo.

Os animais presentes na obra tellesiana são, em sua maioria, os retratados por fabulistas antigos e medievais e pelos contistas orientais. No entanto, Lygia opta por uma variante perturbadora do "eu me sirvo dos animais para instruir os homens" de La Fontaine, em que o fascínio ríspido do retrato dos seres humanos reverbera nos animais. Esses seres literários, corrompidos pelo sofrimento, o despeito ou a desconfiança, refletem de modo perturbador os defeitos humanos que incidem sobre eles.

Nesse sentido, o "sugestivo impressionismo recatado [...], o estilo sui generis, misto de sutileza e força, escrita que mais sugere do que mostra" (Coelho, 2002, p. 387), faz com que o percurso literário de Fagundes Telles seja brasileiro, também e paradoxalmente, ao não sê-lo, pois como renovadora sucessora - não simplesmente herdeira - da linhagem machadiana, a autora opta por manter de pé as ruínas das verdades e dos valores tradicionais para realizar seu cáustico retrato da sociedade contemporânea e, igualmente, da condição humana. Numa situação insustentável, retrata de modo ousado essa parte da sociedade que se agarra, agonicamente, a uma inoperante ilusão vital. Uma farsa, aliás, tão inoperante que a autora do neomachadiano "Missa do galo" a contamina com elementos fantásticos, como os animais pensantes.

A obra da escritora paulistana aproxima-se, assim, do fantástico que, de acordo com Robert E. Scholes, apresenta "uma resposta para a grande questão de onde a ficção poderia chegar depois do romance realista" (1967, p. 11, tradução nossa). No entanto, os alicerces da escrita tellesiana são as convenções realistas, problematizadas pela intrusão de sequências fantásticas, num modo de narrar sutil, penetrante e medido.

Numa cultura amedrontada por vampiros e outros monstros pseudogóticos tão triviais como os tapizes voadores do maravilhoso oriental setecentista, o questionamento das convicções racionais, retomado da literaturização gótica da angústia, revela, mais uma vez na história da literatura, uma originalidade perturbadora.

De acordo com o novo manual de história natural que a Prémio Camões cria em seus textos, a fronteira já não é estabelecida entre homem e animal, mas entre seres instintivos e seres pensantes. E repare-se que, apesar dessa mudança, nas narrativas, o homem julga-se o único ser dotado de discernimento, e isto, do ponto de vista crítico, será muito produtivo. Que o gato e o cão, como os outros bruta, aparentemente se caracterizem ainda pelo instinto, vai permitir-lhes observar o lado oculto, indecoroso, da humanidade. 
O animal doméstico parece continuar a ser o "amigo agradável" de que falava George Eliot, isto é, aquele que não faz perguntas e não critica, mas, na verdade, não o é. A mudança imperceptível de várias das personagens, que se metamorfoseiam em animais, não horroriza quem as rodeia, pois diferentemente de Gregor Samsa, seu mutismo os protege da monstruosidade.

Para os protagonistas do romance As horas nuas e do conto "O crachá nos dentes", sua nova existência mestiça é traumática. $\mathrm{O}$ cão protagonista do relato torna-se cão num momento de crise, provocado pelo desamor, enquanto Rahul surge no romance condenado a lembrar possíveis vidas e amores passados, por ser um "gato sem raça. Castrado e com memória" (Telles, 1989, p. 111).

$\mathrm{Na}$ animalidade, eles não encontram qualquer promessa de liberdade, só a vivência trágica dessa nova condição, sob o efeito da perda da humanidade, o que nos orienta para a reflexão sobre o "humano" e sobre o que há de "humano" nos homens num sentido pós-moderno. O fantástico torna as próprias figuras focais, principalmente o gato Rahul, vozes sem autoridade plena, uma vez que seus relatos apresentam lacunas e equívocos, pois, em suas rememorações, nem sempre conseguem delimitar a fronteira entre a lembrança e o sonho, o que reforçará a procura de verossimilhança, destacada por Ascensión Rivas Hernández em seu estudo sobre As horas nuas:

O autor implícito do romance está preocupado em resolver o problema decorrente da introdução da magia em um contexto realista e, portanto, tenta justificá-lo sempre que possível. Nesse sentido, é necessário compreender a referência [...] às "histórias do tempo em que os animais falavam" (p. 31), que, ao ligar o texto a dois gêneros de longa tradição a fábula e o conto - colocam-no em uma corrente da literatura canonizada em que essa forma de fantasia é plausível. A explicação, porém, se estende a outras áreas do romance, o que significa que Lygia Fagundes tem interesse em manter a credibilidade do fantástico em seu contexto, como preconiza Aristóteles. É por isso que também busca razões internas, de conteúdo, e que às vezes tenta esclarecer a aparência do animal comparando-a com a de outros personagens considerados ainda mais absurdos. É por isso que o gato questiona a figura da donzela Dionísia, e ironicamente se pergunta que coisas terríveis ela teve que fazer em uma vida passada para voltar para dentro do corpo de uma mulher negra e escrava da religião (2014, p. 25-26, tradução nossa).

Ainda, a mestria ficcional da autora serve-se da referida incerteza para manter uns duvidosos limites entre o real e o irreal, mais perturbadores do que um relativismo absoluto ou do que as figuras brumosas que, à meia-noite, aparecem em certas obras fantásticas. Para o efeito, esses protagonistas foram dotados de um retrato moral e sentimental formado por extravagâncias ou particularidades irónicas. A título de exemplo, podemos referir o momento em que o gato aumenta de peso por causa do conforto de ser animal de estimação (Telles, 1989, p. 30), mas está angustiado pela dúvida, pois não sabe se terá inventado a história da transmigração, como "simples necessidade de compensar a forma atual através da fantasia" (Telles, 1989, p. 54). Igualmente, percebemos a triste ironia da história do cão que pensa - e que sabe rezar e gosta "de ouvir música e de ficar olhando as nuvens" (Telles, 1996, p. 62) - ter aprendido, do treinador do circo em que trabalha, "muitas coisas, tais como falar no telefone, fazer piruetas e dançar" (Telles, 1996, p. 60).

As duas personagens carecem da plenitude dos homens assentes na realidade e, por isso, a exposição das suas vivências é complementada pela atenção às pessoas que os rodeiam. $O$ centro dessas ficções seria, assim, o das ligações entre as diversas existências individuais que, como assinalara José Paulo Paes (1998, p. 70), convergem sob o signo de uma impossibilidade: "O título de um dos livros de Lygia Fagundes Telles, Histórias do desencontro, bem poderia servir de lema para toda a sua obra de ficção".

Pensemos nessa testemunha relevante, embora não totalmente fidedigna, o gato que pensa. É um gato semelhante ao dos romances românticos, pois espia a intimidade da casa, mas, ao mesmo tempo, é totalmente diferente, pois também aproveita a intimidade para destacar seu distanciamento, como evidencia a seguinte passagem: 
Sair desta vida no nível do chão. Sem horizonte, fechado por muros, móveis, portas. A longa convivência com o rodapé. Com os sapatos. Identifico os donos dos sapatos antes mesmo de encará-los ou de ouvir suas vozes. Rosona e sua mania com sapatos, compra dúzias deles, a maioria endurece intocada. No Verão, costuma circular descalça pelos lances da escada que mandou atapetar. Gregório e seus sapatos gastos, as solas guardando seu jeito de pisar um pouco para fora, de quem não quer ser notado. Você precisa comprar sapatos com urgência, Rosona repetia. Ele concordava, distraído. Diogo e seus belos sapatos italianos. Os sapatos sem salto da pequena Ananta (Telles, 1989, p. 29).

Essa lúcida visão a rés-do-chão permite-lhe examinar o temperamento dos outros. Como um arqueólogo das ruínas amorosas, Rahul relaciona sua incerta estória com a história de sua proprietária, Rosa, uma atriz decadente, viúva de um intelectual torturado pela ditadura, abandonada pelos sucessivos amantes, desprezada por uma filha "a todo vapor com seus velhos, uma Lolita sul-americana" (Telles, 1989, p. 127), tratada por uma analista tão devotada à vida dos pacientes que carece de vida própria e que se autorretrata como:

Atriz medíocre, mãe egoísta, amante infiel e dona-de-casa descuidada, ela disse hoje para o espelho com expressão de desafio [...]. Impregnou-se tanto dos papéis que representou que facilmente passa de um papel para outro - fragmentos que vai juntando e emendando nas raízes, dependendo da conveniência (Telles, 1989, p. 92).

Só, Rahul vai refletir sobre a aflição da busca da felicidade e a hostilidade do outro vivida por ele próprio e por Rosa, numa meditação complementar à tentativa memorialística de sua dona que, por meio do monólogo interior, oferece-nos uma entrada parcial a sua interioridade. Ela é a protagonista central do romance, mesmo porque o gato e a analista, os outros coprotagonistas, estão lá, em primeiro lugar, para registar e examinar até ao último suspiro da atriz.

No entanto, o gato não é simplesmente um espelho narcísico para a atriz, pois suas meditações assumem um teor universalizante relativamente aos dois grandes temas da arte, amor e morte, e aos traumas ligados a eles, o medo do abandono e da caducidade, respetivamente.

Com pungente ironia - distante já do gai-savoir du veillir de Sand -, o romance capta as pequenas tragédias da maturidade, como a perda do último amor, a inversão das relações maternais e filiais ou o abismo existente entre a idade civil e a idade sentida. Contudo, a ilusória saudade da Grandeza dessa atriz em horas baixas não é mais do que um idílio fútil com a melancolia, pois, na superficialidade de suas relações afetivas passadas e presentes radiografadas no terrível autorretrato antes citado - , é que reside o verdadeiro problema de sua conturbada vivência da maturidade.

Contrariamente à atitude saudosista de Rahul e Rosa, Ananta, terceiro vértice do triângulo ficcional, idealiza um vago futuro, que compense o vazio existencial do presente, e projeta suas esperanças no mito das metamorfoses, que representa o retorno do inconsciente e das pulsões primitivas, referido por Gaston Bachelard.

O brilho das metamorfoses de Ovídio ou de Kafka ilumina novas abordagens ficcionais do topos, entrelaçando influências dos dois autores. A par da fina sombra kafkiana, presente nas transformações que focavam a animalização como rebaixamento, encontramos outra alomorfia que, apesar de secundária no enredo, tem uma notável relevância simbólica.

A alomorfia, como na escrita kafkiana, parece, simplesmente, ocorrer. Não sabemos ao certo se a incerta transmutação do vizinho de Ananta é um reflexo de seus anseios ou se ela se produz contra sua vontade. Sabemos, isso sim, que é reflexo dos desejos latentes de Ananta, que vivencia em segunda mão uma transformação que parece entrecruzar a matriz kafkiana com os antecedentes clássicos.

Numa inversão e apropriação contemporânea da transfiguração de Daphne nas Metamorfoses, Ananta, a metódica profissional, parece desejar conquistar a condição de mulher de que Daphne ansiava libertar-se. É a experiência "vampirizada" da metamorfose do misterioso vizinho que possibilita essa aspiração:

vigiou o relógio (quase 8 horas) enquanto desembrulhava outro tablete (o pensamento NELE), mastigando e calculando rapidamente o tempo que lhe sobrava para recomeçar o 
ritual da véspera. A coragem. A paciência. Apanhou o disco que estava em primeiro lugar na prateleira (Bach) e que seria o fio-guia na noite do Vizinho que chegava tão desprotegido. E poderoso com seu impermeável preto e sua solidão. No passo de quem carrega um segredo agora repartido, ele sabia que no andar embaixo estava a cúmplice, mais do que cúmplice, a amiga (Telles, 1989, p. 70).

Os enigmáticos sons no apartamento do Vizinho fascinam à solitária Ananta, levando-a a acreditar no mito das metamorfoses com que identifica aqueles ruídos. Assistimos, portanto, a uma plausível transferência do plano do real para o do fantástico, dominada por um impulso sexual radicalmente oposto à frieza científica da Ananta analista e, como indicava José Paulo Paes (1998, p. 82), mesmo a certas convicções da Ananta feminista militante.

$\mathrm{O}$ efeito de estranhamento que essa transferência provoca no leitor, forçado a observar com um olhar não realista a figura mais familiar e tranquilizadora do conto, revela-nos um dos mais irônicos atrativos da escrita tellesiana: a ambiguidade. Ela demanda o esforço do leitor - quem procura auxílio nas personagens mais sólidas para interpretar a indeterminação do enredo - , para depois abandoná-lo, frequentemente, confuso, do lado de fora da história.

Ainda, se focamos a outra metamorfose mencionada, a do cão de "O crachá nos dentes", observamos uma fidelidade proverbialmente canina, mas pouco edificante, segundo a interpretação proposta por Karl Kraus em Ditos e desditos, pois o cão é fiel ao homem, não ao cão. No entanto, o híbrido protagonista combina a inércia dessa fidelidade com uma conformidade bem humana, que ecoa, portanto, a desaprovação da autora perante as sombras da nossa condição.

O cão, após um período "humanoide", retorna à condição animal ao sofrer o desamor e o paradoxo dos sentimentos humanos: "Fiquei flamejante. Penso agora que flamejei demais e o meu amor que parecia feliz acabou se assustando, era um amor frágil, assustadiço. Tentei disfarçar tamanha intensidade, o medo de ter medo" (Telles, 1996, p. 60). A sensação de degradação, que alimenta a indócil submissão do protagonista perante sua recuperada condição animal, filtra a absurda perversidade humana, ao focar a violência do treinador de circo, que, "de roupa vermelha com botões dourados", queima "as patas transgressoras" daquele cãohumano, quando percebe sua relutância em continuar "dançando com meu saiote de tule azul" (Telles, 1996, p. 60).

Esse protagonismo do extraordinário no questionamento da grandeur humana é também evidente na metamorfose do relato "Lua crescente em Amsterdã", no qual ela recupera seu caráter violento e monstruoso, contrariando o horizonte de expetativas dos leitores, criado pelas metamorfoses anteriores. Na atmosfera de ambígua tensão que domina o conto, o desejo do protagonista de se tornar passarinho e o de sua companheira de se tornar borboleta condensam o mal-estar existencial que ele exprime na seguinte - enigmática - afirmação: "Sei lá. Não quero é voltar a ser gente, eu teria que conviver com as pessoas e as pessoas..." (Telles, 2002, p. 155).

Esse desejado metamorfismo do jovem casal desavindo deriva, no final do relato, do instinto, da pulsão mais primitivamente destrutiva, que subverte os valores convencionais representados por esses animais idealizados pela cultura. Assim, a autora, extraordinária cultora da ambiguidade, concebe um "enredo", "diluindo nos feelings, sensações, percepções, revelações ou sugestões íntimas" (Gotlib, 1985, p. 30), inserindo o leitor num ambiente pouco claro nos vínculos entre a realidade e a ficção, para assim, debilitar suas suspicácias, quando o leva à esfera do mistério. A dubiedade narrativa só parece deixar claro o anseio de fuga dos protagonistas a respeito de um provável antigo amor vivido por eles e representado agora como demoníaco.

No entanto, mesmo essa aparente clareza é posta a serviço da ambiguidade e da habilidade narrativa da autora para causar surpresa, pois, afinal, o desencanto tellesiano a respeito de uma humanidade cruel acaba por idealizar uma metamorfose que expõe os sentimentos de bestialidade desses animais aparentemente mansos. É assim que as mutações transformadoras, enquanto mimesis, convertem as duas personagens cruéis em animais silenciosos, mas detidos numa violenta e simbólica atitude de agressão, a do "passarinho de penas azuis bicando com 
disciplinada voracidade a borboleta que procurava se esconder debaixo do banco de pedra" (Telles, 2002, p. 155).

A "moderação" do fantástico não espetacular apresentado nestes relatos ilustra o preceito de que "o fantástico, para ser convincente, deve ser discreto" (Vax, 1972, p. 112), preceito já enunciado por Dostoievski. O escritor russo recusava as narrações excessivamente implausíveis, aquelas que não podiam ser apresentadas como "reais", numa concepção do fantástico que corresponde à visão lygiana, que pode, por sua vez, ser filiada a uma tendência da escrita contemporânea: "O fantástico moderno revela-se cada vez menos capaz de assumir um papel transcendental ou de inventar supermundos. Continua a articular o desejo absoluto, mas seus fins não são mais conhecidos: romper os limites finitos, humanos, torna-se sua única (im)possibilidade" (Jackson, 1981, p. 79, tradução nossa).

O universo ficcional dos relatos e do romance analisados é um universo que é, simultaneamente, real e fantástico, mas, atente-se a que, como dizia habitualmente o narrador siciliano Andrea Camillieri, nas note dell'autore com que finalizava seus romances: "Se a fantasia foi capaz de coincidir com a realidade, a culpa é, na minha opinião, da realidade" (Camillieri, 1996, p. 247, tradução nossa).

Nessa ambiguidade profundamente perturbadora que domina a ficção tellesiana, a par dessas metamorfoses encontramos outra expressão desse princípio, pois os eventos podem ainda ser, por vezes, incríveis, mas não são expostos como fantásticos. Há nesses contos dois planos imprecisos: o do real e o da projeção, confinante com o do onírico. Neles, assistimos a um processo de "contaminação" mútua entre os humanos e seus animais de estimação, que dificulta a distinção entre a bestialidade e a humanidade, representada pelos valores da classe burguesa.

Nessa outra vertente ficcional, os animais deixaram de ser animais falantes e, consequentemente, a visão íntima do humano nos é oferecida diretamente por seus donos. Esse deslocamento permite-nos intuir o caráter trágico de um conjunto de existências que nos são apresentadas, mais uma vez, de modo ambíguo.

Como prenunciava o enredo de "Lua crescente em Amsterdã", a natureza das personagens humanas, como a animalitas, é agora sugerida de modo escuro e problemático, pois o animal continua a ser o miroir d'encre, no qual o homem, observando-se, descobre sua imagem distorcida, com feições de fera ou de animal doméstico.

A maior escuridão de relatos como "Passarinho" ou "Tigrela" evidencia o modo como a escritora decidiu esboçar o retrato crítico do ser humano através da dúvida e não da censura, como parece demonstrar a fácil constatação de Lygia Fagundes Telles ter explicado sua escrita, focando, de um modo geral, a gênese de suas fiç̧ões e não sua significação.

"Passarinho" concentra-se numa das realidades mais atrativas para a literatura moderna e contemporânea, a família, que, com seus segredos e mentiras, alicerça, como sabemos, o romance como gênero burguês e, ainda, certa ficção contemporânea compatível, em sua amarga crítica social, com as ruínas que aquele romance vaticinava.

Um pai, uma mãe e um filho formam um triângulo narrativo em que o protagonismo é dado à figura do "homem de família". O exame da condição humana que preside ao texto é penoso e, ao mesmo tempo, irônico, pois o lúcido protagonista tem mais em comum com seu animal de estimação do que com sua esposa e seu filho. Um filho néscio e embrutecido que masca chiclete e considera o pai ignorante, por não poder identificar a espécie do pássaro que achara na rua: "Você não sabe nada mesmo, Pai, nem marca de carro, nem marca de cigarro, nem marca de passarinho, você não sabe nada" (Telles, 2002, p. 165).

Essa percepção exterior e superficial dá início à nossa problemática aproximação à essência do protagonista, pois a autora esboça apenas retratos fragmentários dele e de sua família, desviando nossa atenção do externo, o visível e o superficial para as profundezas de uma implícita reflexão sobre o grande tema do sentido da existência.

Ao contrário do que decide o professor de matemática do relato homónimo de Clarice Lispector, o protagonista criado por Fagundes Telles já não é capaz de viver em função de princípios "padronizados" e, por causa disso, pende para a aparente animalização de sua 
conduta, não da sua consciência. O passarinho, como o cão de "O crime do professor de matemática", figura a coragem da soberania e da liberdade, que motiva a reavaliação dos princípios vitais e éticos de seu dono. Ambos colaboram, como espelhos, no autoquestionamento dos problemáticos heróis dos relatos. Neles, a fronteira entre a existência animal e a existência humana torna-se móvel, pois o leitor é convidado a ponderar a diferença e a semelhança relativamente ao animal, mas essa meditação contempla, essencialmente, a natureza humana.

Nos contos de Lygia Fagundes Telles, a interioridade do homem torna-se o espaço de convívio e tensão entre a animalidade "antropófora" e a humanidade que nela se corporifica:

Historicamente, o homem só existe nesta tensão: só pode ser humano na medida em que transcende e transforma o animal antropóforo que o sustenta, só porque, pela ação negadora, é capaz de dominar e eventualmente destruir sua mesma animalidade (Agamben, 2002, p. 19, tradução nossa).

No conto, o foco da meditação a respeito do ser humano é deslocado, pois o saber que o protagonista obtém deriva do contato com o animal, mas também, com certeza, do estranhamento e da reflexão que esse inesperado convívio lhe provoca.

O relato leva-nos a pensar que o passarinho é o pássaro convencional da cultura ocidental, fascinada pelo voo das aves desde o primeiro momento em que as observou a elevar-se nos céus. No entanto, se o passarinho se adequa ao consensual simbolismo da ave como representação da anima, a emancipação que figura diverge do ideal desse símbolo. Um homem incomum como o protagonista não poderia ser perturbado por um animal tão típico. Para ser perturbador, o ensinamento que pode oferecer ao protagonista deve ser mais complexo e, consequentemente, o voo leva à ave a mudar de rumo simbólico, para o do "passarinho burro!" que "fugiu e acabou aí, na boca do gato!" (Telles, 2002, p. 167), como nos dá conta, numa pobre interpretação do acontecimento, o filho do protagonista.

Esse desenlace infausto torna escuramente exuberante o simbolismo da fuga do passarinho à procura da liberdade e, por extensão, também a secreta ambição do protagonista, que o leva a abandonar o lar, uma feliz decisão que os outros identificam com a loucura. ${ }^{1}$

Essa dialética da futilidade leva ao círculo do protagonista uma espécie de aporia, pois, na atitude da personagem que opta pela perturbadora e silenciosa recusa da sociedade, eles só conseguem intuir os indícios de um comportamento alienado: "Um ano depois os moradores do bairro ainda se lembravam do homem de cabelo ruivo que enlouqueceu e sumiu de casa" (Telles, 2002, p. 164).

No entanto, é essa disposição que impede o protagonista de animalizar-se, de mutar-se de modo irrevogável num "animal de costumes", como o filho descobre, sem compreender o que nos está a revelar: "o Pai era um homem alto, nunca tinha reparado antes como ele era alto [...] estranhou o andar do Pai, firme e reto, mas por que ele andava agora desse jeito?" (Telles, 2002, p. 167).

No relato "Tigrela", presenciamos outro processo de projeção humana menos construtivo, mas analogamente edificante. Com uma modulação lúgubre, é narrada uma nova troca entre os dois lados da instável fronteira entre humanidade e animalidade, operada através da perversão da fera, adestrada numa truculenta inteligência emocional.

"Tigrela" é um dos mais violentos retratos do amor de Fagundes Telles. Uma vez satisfeito o desejo, tudo se desintegra em pedaços. Nesse conto é relatada a degradação de um relacionamento amoroso, por causa do qual Tigrela - uma personagem obscura, pois não é elucidado se se trata de um ser humano ou de um animal - padece de uma nova e impiedosa educação sentimental.

A "tigrela" troca sua condição selvagem por outra ferocidade íntima, que subverte alguns dos valores do simbólico animal literário. Nesse sentido, destaca-se no conto a mordaz

\footnotetext{
${ }^{1}$ Nesse sentido, no âmbito da literatura brasileira, o princípio "escritural" e ontológico que fundamenta o conto "História de passarinho" poderia dialogar, entre outras, com duas desassossegadoras ficções contemporâneas: Tu não te moves de ti, de Hilda Hilst, e o concentrado conto "Aí pelas três da tarde", de Raduan Nassar.
} 
crueldade em relação às quimeras próprias de um dos grandes ideais literários: o amor. O relato exprime uma irresolução que sugere, de modo renovador, a ideia da possível inviabilidade das relações felizes. Nessa ocasião, o árduo convívio entre o universo masculino, frequentemente representado como hipócrita face ao amor, e o feminino, marcado pelo anseio do ideal, é transferido para o âmbito exclusivamente feminino, como evidencia a conversa que a narradora mantém com Romana, a companheira da "tigrela":

Mas Romana, não seria mais humano se a mandasse para o zoológico? Deixe que ela volte a ser bicho, acho cruel isso de lhe impor sua jaula, e se for mais feliz na outra? Você a escravizou. E acabou se escravizando, tinha que ser. Não vai lhe dar ao menos a liberdade de escolha? Com impaciência, Romana afundou a cenoura no sal. Lambeu-a. Liberdade é conforto, minha querida, Tigrela também sabe disso. Teve todo o conforto, como Yasbeck fez comigo até me descartar.

E agora você quer se descartar dela, eu disse (Telles, 2002, p. 124-125).

Somos defrontados com um atípico fenômeno de contaminatio, em que a inconstância convencionalmente masculina é legada à mulher que a sofrera, enquanto que a obstinada esperança feminina é transmitida à nova figura subalterna: a tigrela domesticada pela protagonista. Em suma, o relato é uma bomba literária que indica que a desumanidade é geral e não genérica, e que o ser humano só precisa de uma oportunidade para desvelar seu egoísmo. Assim, perante o ciúme sentido pela tigrela a respeito de Romana, ela declara numa perfeita confissão de seu narcisismo: "Acho que eu gostaria de ter um unicórnio, você sabe, aquele lindo cavalo alourado com um chifre cor-de-rosa na testa, vi na tapeçaria medieval, estava apaixonado pela princesa que lhe oferecia um espelho para que se olhasse" (Telles, 2002, p. 125).

A despeito de ter tornado tigrela vegetariana, porque "carne dá mau hálito" (Telles, 2002, p. 122), Romana não é capaz de refrear sua ferocidade, que não é a associada ao tigre emblemático do bestiário, mas à ferocidade provocada por sua "civilização". Como Deleuze e Guattari, Fagundes Telles parece substituir a noção do ser pela do devir, dominado por uma indeterminação que impossibilita a delimitação clara das fronteiras entre o homem e o animal. Assim, no conto são vagamente referidos os "dois terços de tigre e um terço de mulher" (Telles, 2002, p. 118): é essa a parte feminina que desperta a violência da personagem, dominada por um amor assimétrico e que só encontra uma solução na violência exercida contra Romana e contra si própria, pois depois de agredir sua "proprietária", "ficou deprimida e na depressão se exalta, quase arrasou com o jardim, rasgou meu chambre, quebrou coisas. No fim, quis se atirar do parapeito do terraço, que nem gente, igual" (Telles, 2002, p. 118).

Por oposição ao império dos bons sentimentos falsificados, Lygia Fagundes Telles concebe esse novo ser ambíguo - que, de certo modo, continua a linhagem do enigmático "The tyger" do poema de Blake ou do elusivo "El otro tigre" de Borges -, privado da capacidade de comunicar e que, portanto, só pode exteriorizar seu mal-estar através das respostas mais instintivas, a da agressão e a do desespero.

E é esta descoberta que faz com que Romana se comporte de modo suicidário à espera de um desenlace que não a obrigue a assumir a responsabilidade por suas decisões: "Volto tremendo para o apartamento porque nunca sei se o porteiro vem ou não me avisar que de algum terraço se atirou uma jovem nua, com um colar de âmbar enrolado no pescoço" (Telles, 2002, p. 126).

"História de passarinho" e "Tigrela" são, por conseguinte, dois modelos da potência simbólica dessas outras figuras silentes, do animal-espelho côncavo e convexo, respectivamente, isto é, aquele que nobilita ou degrada a condição dos protagonistas.

A par dessa narração do quase dito pela mudez dos animais, deparamos com um outro valor desse silêncio nos contos. Num estágio de animalização ainda mais intenso, os bichos são representados com uma inércia que evoca os valores emblemáticos do bestiário. Animada por uma vontade inquiridora, a autora distancia-se das delimitações e das explicações, porque desconfia do modo como elas condicionam nossa percepção da realidade. E assim, em seu oblíquo retrato da burguesia, Fagundes Telles intercala em sua escrita insinuações simbólicas, como o perfil que a mãe protagonista de "Uma branca sombra pálida" desenha de sua filha. 
Impressionada com o trágico desencontro entre ambas, cujo desfecho foi o suicídio da filha, a protagonista condensa o desassossego que lhe provoca essa rejeição absoluta no símbolo convencional da proteção: "Muito parecida com o pai a pequena Gina, seria um bicho-deconcha se morasse no mar" (Telles, 1996, p. 167).

Todas as luzes da existência da protagonista foram desligadas: o marido e a filha estão mortos, mas, mesmo assim, seu antagonismo sobrevive por meio da angústia e da suspeita. Assim, a mãe é um exemplo paradigmático de narrador não confiável, pois o relacionamento opressivo que estabeleceu em relação à filha faz com que ela justifique perante o leitor a dominação a que pretendia submeter a filha, baseada na desconfiança e nas suspeitas quanto à provável relação lésbica que Gina mantinha com uma amiga, Oriana, e, como se isto fosse pouco, interprete para nós o suicídio da filha como um ataque: "foi suicídio. Acho que queria apenas me agredir, seria uma simples agressão mas desta vez foi longe demais. $O$ pai tinha esse mesmo estilo ambíguo, não ia direto ao alvo, contornava. A diferença é que era mais esperto, não correria o risco de fazer figurações com a morte" (Telles, 1996, p. 155).

Porém, essa exposição delirante do que aconteceu não é o apogeu da desgraça familiar, momento em que é desvendado de modo concludente o caráter contraditório do domínio sentimental que a mãe pretende manter relativamente à filha, projetado agora na figura da amiga-amante:

Até quando Oriana vai se empenhar comigo nessa polêmica? É uma exibicionista, deve sentir prazer nas competições. Mas logo vai conhecer outra, é evidente. Ao lado das suas rosas ressequidas ficarão apenas as minhas rosas brancas. Difícil explicar, mas quando isso acontecer, esta será para mim a sua maior traição (Telles, 1996, p. 168).

A protagonista criou uma intimidade tão abissal que permite mesmo a troca do alvo de seu sufocante matriarcado, servindo o conto como uma boa ilustração do modo como, com frequência, os relatos de Fagundes Telles se alicerçam em "complicações sentimentais", provocando "substituições egoístas de parceiros" (Santiago, 1998, p. 103).

Nesse sentido, no conto "Você não acha que esfriou?", presenciamos outro caso dessas agônicas projeções sentimentais. Num novo envolvimento problemático, somos defrontados com um triângulo amoroso pouco convencional, pois é a figura do marido enganado que domina in absentia os outros.

A protagonista, Kori, virada na cama para a parede, "uma parede completamente branca, nenhum quadro, nenhum furo, nada", perante a convição de ter sido apenas um "elo" entre seu amante e o verdadeiro objeto de seu amor, Otávio, o marido de Kori, anela escapar e pensa no "mínimo inseto a se enfiar aflito na frincha da argamassa de cal, e, forçando a entrada, até desaparecer" (Telles, 1996, p. 39).

Esse pequeno animal materializa a natureza abominável da relação: a busca alucinada do objeto impossível do amor através de um desalmado exercício de conquista. $\mathrm{O}$ simbolismo do inseto denota o teor opressivo desse novo relacionamento, sintetizado no instante de crise no desejo de Kori - só cumprido de modo figurado - de tornar-se, além de irrelevante, imperceptível.

A projeção na perversa intimidade do conto do simbolismo animal evidencia o caráter terrível desse novo sofrimento, magistralmente sintetizado por Letícia, personagem do romance Ciranda de pedra, ao afirmar que "Dante se esqueceu desse círculo no seu inferno: o dos rejeitados" (Telles, s.d., p. 145). Os relatos focam, portanto, situações de tensão em que as personagens, marcadas pelo desequilíbrio emocional, revelam ao leitor atento a sua autêntica natureza: desapiedada, atormentada ou conformada, mas essencialmente covarde e egoísta.

O exemplo paradigmático dessa fraqueza é o protagonista do conto "Verde lagarto amarelo", que, mais uma vez, foca os penosos laços familiares, nomeadamente, os laços entre o protagonista, o "irmão obeso, malvestido e malcheiroso" e o irmão "bonito, inteligente, amado, [que] conseguiu sempre fazer tudo muito melhor do que eu, muito melhor do que os outros" (Telles, 2004, p. 43).

Já adulto, o protagonista é um escritor de sucesso que cultiva a escrita como seu jardim privado, resguardado da indesejada sombra do irmão, pois desde a infância se sentira 
"condenado ao seu fraterno amor" (Telles, 2004, p. 43). Apesar da dolorosa idolatria da mãe por esse outro filho, a retidão e a honestidade do irmão neutralizam qualquer desculpa que justifique a hostilidade do protagonista. À luz dessa obscura familiaridade, a suspeita de que o irmão quer tornar-se escritor, isto é, invadir o espaço de liberdade e segurança do protagonista, provoca a única resposta possível, a mesma fraqueza da infância, quando se ocultava e "subia na figueira, ficava imóvel, um lagarto no vão do muro" (Telles, 2004, p. 43). À procura de uma imperceptibilidade semelhante à de Kori, o protagonista do relato torna-se um "verde lagarto amarelo", uma animalização simbólica que ilustra a concepção da intimidade de Lygia Fagundes Telles: uma estampa de um caos intuído, mas sempre suspenso, formada por nuances mutáveis e por uma viscosa tensão.

E, ainda, esse simbolismo modesto dos animais menores delimita outra fronteira crítica em que, novamente, a distância entre o animal e o humano parece prestes a ser aniquilada. Destarte, com a ajuda de uma lente de aumento, no iniciático relato "A rosa verde", é-nos apresentada, através da lupa de uma menina órfã, uma miniatura de nosso mundo. Seu discurso, através da projeção da lógica humana numa sociedade "gulliverizada", destaca a inviabilidade de qualquer tentativa de "desumanizar" nossa interpretação da natureza:

Fiquei apavorada, mas aumentados eles eram horríveis! Fui me acostumando quando fui achando que todos esses insetos eram parecidos com a gente nas suas festas. Nas suas brigas. Trabalhavam sem parar e também vadiavam como naqueles ajuntamentos de domingo no largo do jardim, gostavam de se divertir. E gostavam de brigar [...]. Na lupa aparecia até a cara preocupada da formiga carregando no ombro o ferido ou o morto, como faziam os soldados nas fitas de guerra (Telles, 1996, p. 141-142).

"A rosa verde" poderia ser filiada a outras grandes ficções contemporâneas, pois se aproxima do exame crítico-alegórico de comunidades humanas procedendo como sociedades de insetos, à maneira, por exemplo, do exame presente na escrita de Thomas Bernhard.

De modo semelhante, em textos concebidos com um magnífico sentido da narração, Lygia Fagundes Telles simboliza a angústia do homem sobre um fundo de traumas, fantasmas e inércia. Apenas quando a autora idealiza a animalidade como instrumento de exame histórico, a rispidez da inércia se transforma em agressividade, emergente em "A rosa verde" e evidente em "Seminário dos ratos", relato baseado no uso violento do simbolismo dos animais menores como espelho do absurdo social.

Como explicou a própria escritora numa entrevista, "Seminário dos ratos" é uma cáustica e satírica interpretação da incoerente lógica política da ditadura. Novamente, esse relato adentrase no espaço do fantástico, ao espelhar através da irrupção dos ratos, isto é, da figuração surrealista dos eventos históricos, o fanatismo dos líderes da ditadura, incapazes de ver e de perceber a magnitude de seus problemas.

Isolados numa casa de campo, os representantes do governo realizam, acompanhados por diversas delegações estrangeiras, o VII Seminário dos Roedores para discutir seu principal problema a uma distância prudente do mesmo:

Ah, e aquela eterna tecla que não cansam de bater, que já estamos no VII Seminário e até agora, nada de objetivo, que a população ratal já se multiplicou sete mil vezes depois do I Seminário, que temos agora cem ratos para cada habitante, que nas favelas não são as Marias mas as ratazanas que andam de lata d'água na cabeça - acrescentou contendo uma risadinha. - O de sempre... Não se conformam é de nos reunirmos em local retirado, que devíamos estar lá no centro, dentro do problema. Nosso Assessor de Imprensa já esclareceu o óbvio, que este Seminário é o Quartel-General de uma verdadeira batalha! E que traçar as coordenadas de uma ação conjunta deste porte exige meditação. Lucidez (Telles, 2004, p. 50).

Numa inesperada subversão dos valores convencionalmente atribuídos aos ratos - rejeitados por Noé como "passageiros" merecedores da salvação ou por Winston Smith, a quem esses seres, convencionalmente abjetos, provocam terror em 1984, para só citar dois exemplos —, Lygia Fagundes Telles materializa neles o povo, condensando o processo de desumanização que marca certas estratégias típicas dos estados totalitários e, ao mesmo tempo, ironicamente, através de sua 
insurreição, a natureza resiliente e próxima desses animais, que sempre se encontram mais próximos do nosso mundo - pretensamente asséptico e seguro - do que pensamos.

Tal como foi destacado no ensaio Literature and animal studies, de Mario Ortiz Robles (2016, p. 145, tradução nossa), "o coletivo animal oferece possibilidades de contagem política [...] os coletivos animais costumam carregar o fardo figurativo dos movimentos sociais". Como essa ideia sugere, essa representação leva a leituras alegóricas. No entanto, se a alegoria, de acordo com o autor, ainda continua a ser entendida de modo convencional, como uma estrutura retórica didática através da qual "damos forma a qualidades e situações ambíguas por meio da personificação: amor, justiça, coragem etc." (2016, p. 145, tradução nossa), nosso conto, como as grandes alegorias, não é completamente alegórico, do mesmo modo que os grandes romances realistas nunca são completamente reais (Scholes, 1967, p. 99).

A complexidade aumenta, portanto, no âmbito em que o elemento estranho se manifesta de modo mais ambíguo, tornando a complicação problematicidade, pois os diferentes níveis de interpretação que a irônica escuridão do conto permite situam-nos numa vasta zona de sombra, que possibilita tanto uma compreensão fantástica, quanto alegórica, perigosa para o fantástico, pois a alegoria estimula uma leitura não literal, que, como indicava Tzvetan Todorov, também não tem nada de sobrenatural. O conto poderia situar-se, assim, num desses dois polos ou entre eles, na escala de subgêneros situados entre o fantástico, que pertence a esse tipo de textos que devem ser lidos em sentido literal, e a alegoria pura, que observa só o sentido segundo e alegórico (Todorov, 1970, p. 69).

Para sublinhar esse ironicamente dúbio questionamento dos princípios "civilizados", a autora concebeu o animal de modo não antropomórfico, como mecanismo de representação acelerada da violência narrada pelo único sobrevivente:

nesse instante a casa foi sacudida em seus alicerces. As luzes se apagaram. Então, deu-se a invasão, espessa como se um saco de pedras borrachosas tivesse sido despejado em cima do telhado e agora saltasse por todos os lados numa treva dura de músculos, guinchos e centenas de olhos luzindo negríssimos (Telles, 2004, p. 59).

Esta caricatura hiperbólica de certa compreensão da nossa civilização, latente na cruel miniatura de "A rosa verde", evidencia a crítica radical consistente em condenar a sociedade, responsável pelos problemas sociais, por suas ações ou sua passividade.

Essa visão crítica da sociedade é exacerbada agora através de uma animalidade nauseabunda, a das pragas do Egito, dos castigos bíblicos e do caos infernal, pois não existe um caos estático e o averno, como afirmou Gilbert Durand, "é sempre imaginado pela iconografia como um lugar caótico e inquieto" (1985, p. 77, tradução nossa). Destarte, a moralidade dessas ficções é racionalista, transformando-se, graças a um certo excesso gótico, em ambiguamente horrendas:

O jogo do medo e do riso está inscrito nos textos góticos desde seu início, uma ambivalência que perturba categorias críticas que avaliam sua seriedade ou trivialidade. A incerteza perpetua as ansiedades góticas no nível da narrativa e da forma genérica, e afeta todas as categorias e limites do genérico ao social (Botting, 1996, p. 168, tradução nossa).

O livro Seminário dos ratos inicia-se com o conto "As formigas" e conclui com o relato "Seminário dos ratos", evidenciando certa continuidade:

Lygia, no primeiro conto de Seminário dos ratos, atribui àquelas formigas nojentas e misteriosas, que aparecem de noite e somem de dia, um papel, embora enigmático, de reconstrução de uma realidade inquietante, enquanto os ratos do conto final resolvem, através da destruição, uma situação de opressão, de perturbante anomalia (Finazzi-Agrò, 2019, p. 6).

Essa continuidade representa uma renovação do bestiário, agora mais sombrio, favorecida pela tensão entre o logos pequeno-burguês e uma angustiosa inspiração tétrica. O entusiasmo gótico da autora retoma a potência da perturbadora turba de "Seminário dos ratos", materializada agora no trabalho das formigas, na agitação de uma multidão terrível que fervilha, como acontecia com os roedores: "Levantei e dei com as formigas pequenas e ruivas que entravam em trilha espessa pela fresta debaixo da porta, atravessavam o quarto, subiam 
pela parede do caixotinho de ossos e desembocavam lá dentro, disciplinadas como um exército em marcha exemplar" (Telles, 2002, p. 110).

No conto, o olhar racional representado pelas duas protagonistas, uma delas estudante de medicina, é problematizado pela invasão noturna e espectral de uma marabunta determinada a reconstruir, noite após noite, o esqueleto de um anão deixado pelo anterior inquilino do quarto, também estudante de medicina.

A angústia domina o conto através de um evidente gosto do terror, mas a riqueza de textos como "As formigas" não se limita a uma superficial estética do horror, uma vez que ele representa certa abertura para a reflexão sobre a natureza humana, como demonstra também o relato "A caçada", em que o estranhamento foca as angústias contemporâneas por meio de uma nova confusão entre pesadelo e real.

As casas e lojas assombradas dos contos de Telles apresentam certa beleza do horrível, que destaca o horror de um modo delicado. No interior da loja de antiguidades, que "tinha o cheiro de uma arca de sacristia com seus panos embolorados e livros comidos de traça" (Telles, 2002, p. 21), a narração concentra-se na beleza inquietante de uma tapeçaria que retrata uma cena de caça, aflitivamente familiar para o protagonista, que visita a loja para observá-la repetidamente.

"Imensa, real só a tapeçaria a se alastrar sorrateiramente pelo chão, pelo teto, engolindo tudo com suas manchas esverdinhadas" (Telles, 2002, p. 27), "engole" e aprisiona o moço - talvez o caçador - no aflitivo papel de animal perseguido. Ao regressar o protagonista a essa cena familiar como objeto da caça, o desfecho desassossegador do conto parece sugerir uma projeção da realidade, nomeadamente, daquelas experiências do mundo e da consciência que não são passíveis de ser submetidas aos processos de representação normais, como o temor ou a angústia.

O território do macabro, cultivado por Fagundes Telles dentro do problemático jardim burguês criado por suas personagens, é depurado de heroínas tímidas, pais tirânicos ou criados cômicos: só resta o estranho e o horrendo, numa radiografia quase - quase, por ser profundamente poética clínica da angústia, um dos estados dominantes na contemporaneidade. Assim, ao filiar-se à grande linhagem de autores que examinaram esse penoso estado, como Dostoiévski, Kafka ou Sartre, a escrita da autora paulistana revela-se divergente do realismo apenas num sentido fecundo e positivo, pois esses autores confirmaram, por meio de suas extraordinárias personagens e histórias, que o realismo stricto sensu é um antiquado souvenir burguês.

Para conciliar de modo equilibrado o conhecimento e a fantasia, é preciso possuir uma invulgar habilidade pendular, que permite que Lygia Fagundes Telles possa introduzir delicadamente um indivíduo normal num universo inquietante ou inserir um indivíduo inquietante num mundo normal. Através desses procedimentos, a fronteira entre o natural e o sobrenatural apaga-se e, quando isto acontece, compreendemos o conforto que ela nos proporcionava face à insuportável estranheza do mundo.

Nesse passeio de mãos dadas com a aflição existencial, acompanhando esses animais desconcertantemente híbridos - que, como "O elefante" drummondiano, resistem "num mundo enfastiado / que já não crê nos bichos / e duvida das coisas" (Andrade, 1995, p. 127) -, a autora não procura delimitar os contornos humanos nem animais dessas criaturas, pois qualquer tentativa de catalogação entomológica seria tão restritiva e empobrecedora quanto as imagens mais convencionais do animal literário. Trata-se de problematizar, por meio de uma nova articulação do animal e do humano, a suspensão do império cego da razão, congelado numa (auto)satisfeita ficção criada durante séculos. Nestas neofábulas de animais-humanos, animais-monstros e outros prodígios que formam a particular "Arca de Noé" construída literariamente pela autora, detectamos, pois, o grande princípio da arte referido por Elias Canetti e que poderia ser salvação da civilização: o de reencontrar aquilo que está perdido através de uma nova visão necessária, filtrada agora por meio da animalidade. Nesse sentido, as criaturas de Lygia Fagundes Telles são mais necessárias do que nunca, num mundo lento, viscoso e entorpecido por causa dos falsos bons sentimentos.

\section{Referências}


AGAMBEN, Giorgio (2002). L'aperto: L'uomo e l'animale. Torino: Bollati Boringhieri.

ANDRADE, Carlos Drummond de (1995). Antologia poética. 30. ed. Rio de Janeiro: Record.

BOTTING, Fred (1996). Gothic. London: Routledge.

CAMILLERI, Andrea (1996). Il ladro di merendine. Palermo: Sellerio Editore.

COELHO, Nelly Novaes (2002). Dicionário crítico das escritoras brasileiras. São Paulo: Escrituras.

DURAND, Gilbert (1985). Les structures anthropologiques de l'imaginaire. 10. ed. Paris: Dunod.

FINAZZI-AGRÒ, Ettore (2019). Amor, humor e terror na ficção de Lygia Fagundes Telles. Estudos de Literatura Brasileira Contemporânea, Brasília, n. 56, p. 1-21. Disponível em: https:// periodicos.unb.br/index.php/estudos/article/view/22669. Acesso em: 11 fev. 2019.

GOTLIB, Nadia Batella (1985). Teoria do conto. São Paulo: Ática.

JACKSON, Rosemary (1981). Fantasy: the literature of subversion. London: Methuen.

PAES, José Paulo (1998). Ao encontro dos desencontros. Cadernos de Literatura Brasileira, São Paulo, n. 5, Lygia Fagundes Telles, p. 70-83.

RIVAS HERNÁNDEZ, Ascensión (2014). Narración y memoria en As horas nuas de Lygia Fagundes Telles. In: RIVAS HERNÁNDEZ, Ascensión; PEREIRA, Helena Bonito (Eds.). Relectura de Lygia Fagundes Telles. São Paulo: Editora Mackenzie; Ediciones Universidad de Salamanca. p. 13-32.

ROBLES, Mario Ortiz (2016). Literature and animal studies. New York: Routledge.

SANTIAGO, Silviano (1998). A bolha e a folha: estrutura e inventário. Cadernos de Literatura Brasileira, São Paulo, n. 5, Lygia Fagundes Telles, p. 98-111.

SCHOLES, Robert (1967). The fabulators. New York: Oxford University Press.

TELLES, Lygia Fagundes (s.d.). Ciranda de pedra. Lisboa: Livros do Brasil.

TELLES, Lygia Fagundes (1989). As horas nuas. 2. ed. Rio de Janeiro: Editora Nova Fronteira.

TELLES, Lygia Fagundes (1996). A noite escura e mais eu. Lisboa: Livros do Brasil.

TELLES, Lygia Fagundes (2002). Pomba enamorada ou Uma história de amor e outros contos escolhidos. Porto Alegre: L\&PM Pocket.

TELLES, Lygia Fagundes (2004). Antologia: meus contos preferidos. Rio de Janeiro: Rocco.

TODOROV, Tzvetan (1970). Introduction a la litttérature fantastique. Paris: Éditions du Seuil.

VAX, Louis (1972). A arte e a literatura fantásticas. Lisboa: Arcádia. 